\title{
An Analysis of Malaysian Political Communication and Its Role in Electoral Process
}

\author{
Suhaimee Saahar@Saabar ${ }^{1, *}$ Ismail Sualman $^{1}$, and Mohd Adnan Hashim ${ }^{2}$ \\ ${ }^{1}$ Faculty of Communication and Media Studies, Universiti Teknologi MARA (UiTM), Shah Alam, \\ Malaysia \\ ${ }^{2}$ Faculty of Communication and Media Studies, Universiti Teknologi MARA, Melaka, Malaysia
}

\begin{abstract}
This paper attempts to discuss political communication in Malaysia especially after the 12th General Elections (GE12). The purpose of this study is to analyse the political efficacy or sense making process which involve analysing the techniques and creative execution that had been used by political parties and its effects on Malaysian voters. The results of GE 12 had fashioned a political tsunami that influenced many important aspects in the Malaysian political landscape, be it national and economic policies, social unity or campaign strategies. Therefore, the main focus of this paper is to discuss the elements and importance of political communication research in Malaysian political communication campaign by focusing on the aspects of creative execution, political information efficacy and sense making process and its impact on the choice of communication tools amongst Malaysian voters.
\end{abstract}

\section{Introduction}

In a democratic country, citizen's participation in the decision making process is important where the process of information exchange make them to exercise the inalienable right [1]. Election provides equal rights to the people to choose their representatives in the government system [2] which serve not only to select leaders acceptable to voters but also to make the leaders accountable for their performance during their tenure in office [3]. Therefore, election and campaign has become a vital platform for any contesting candidates and political parties to position their ideologies and values, through persuasive, systematic and strategic communication and media such as political advertising campaigns. On the other hand, it is the right channel for a citizen or voter to engage, participate and execute their right under the constitution to choose their leaders. In Malaysia, electioneering system is based on three principles, majority votes based on method first-past-the-post system; single member territorial representation; and multi-party electoral system.

*Corresponding author: aimeesavvy@gmail.com 
Since independence in 1957, Malaysia has experienced several general elections mostly contested by political parties and a small number of independent non-party affiliated candidates and these elections occur at regular intervals. The role of political communication in election campaigns is important and less research about in outside the United State of America is more needed to understand its impact on the electoral process [17] on political advertising and political communication in general in Europe, Canada, Israel and East-Asian countries [15]. Even though Malaysia has conducted 13 general elections since the first one in 1955, very little attention was given on research relating to political communication and advertising. As mentioned by Kaid (2001), research on the role of political communication and advertising outside the United States of America is still in its infancy and need more study to understand this phenomenon on the voters. However, there are several important similarities and many interesting differences that warrant some discussion on this subject [16]. The limited number of political communication studies originating in Asia can also be explained by understanding differences in the political systems themselves, which make it difficult to apply theories of media effects developed in Western democracies. For example, the procedures of how political candidates are chosen and elected in Asia, the way people participate in politics and how political information is discussed in the media all differ significantly from political processes in Western nations [18].

\section{Research Gap}

The limited number of this study in this subject can be traced based on the number of research done by local scholars. Most of the past studies on the role of political communication in elections were focused on political media coverage and the effects of the mass media during election $[7,5,11,20]$. There are tendency to study the role and impact of media especially on the political messages such as the effect of political news to voters. Their main concern is to understand how mass media vehicles are used as the main political tools in influencing and persuading Malaysian voters. There is very limited study on political advertising in Malaysia. Even so, the researchers involved on this topic were not from the advertising field. Studies on the effects of media and political campaigns from the perspective of, for instance agenda setting, framing and priming were also few and far between.

It is in fact, difficult to identify precisely the beginnings of political communication research in Malaysia [10]. Among the earliest studies on election is the work of two experienced scholars in communication studies: Syed Arabi Idid and Safar Hashim. Their first book entitled General Elections: A Political Communication Perspective which was published in 1993 marked the birth of Political Communication Studies in Malaysia [10]. Their work were mainly focused on the role of media during election campaigns and the effects of agenda setting on issues, images of party leaders, information seeking and media use especially to the voters. Even though there are admittedly limited research work in this field, studies on Malaysian politics and election campaigns have gained interest among foreign media, especially from the west $[11,24,18]$.

Therefore, this study will focus on the types of communication tools usually used for political electoral process in Malaysia. In particular, this study intends to answer the following research question: Are mainstream media more popular than social media for political electoral process in Malaysia? By achieving the aforementioned objective, it is expected that this study will help to advance current knowledge about the role of mainstream media and social media as the main political tools in influencing and persuading Malaysian voters. In addressing this question, the paper has the following structure. In the next section, the overview of political communication in Malaysia is 
discussed. After that, the methods used are explained thoroughly. In the last part, results and discussions are presented in detail along with the conclusion.

\section{A Review of Political Communication in Malaysia}

According to Kaid and Holtz-Bacha [6], the history of political communication and advertising should begin with the United States of America (USA) because it is here that the techniques of the form were pioneered wherein they have reached their highest level of sophistication. The USA, having become the twentieth century's most successful capitalist power, went faster and further, in commodifying the political process by the utilizing advertising as a strategic approach compared to any other country in the world. It did not take long for the techniques developed in the USA to be exported to Britain and other countries [4]. In Malaysia, political advertising is a field that is still young [5]. As such it is difficult to say when political communication and advertising actually started in Malaysia. Nonetheless, the usage of placards, posters, banners, fliers, radio and television advertisements can be traced back since the election campaigns in the 1960s. It is therefore quite appropriate for researchers interested in political communication and advertising in Malaysia to embark on further research in this field.

Based on some early studies in the mid-1980s conducted by early researcher in this field, political advertisements had been in use is Malaysia since the 1960s. For instance, in the 1986 general election campaign, political parties in Malaysia in particular the National Front (Barisan Nasional) started using political advertisements in the form of caricatures. And during that time, these caricatures which appeared in the mainstream newspapers seemed to have attracted the attention of readers. Although in the 1995 general elections, political advertisements were quite noticeable [6], it was in the 1999 general elections that these advertisements were widely used [7]. Malaysia's 11th general elections campaign held in 2004 witnessed changes in political campaign with the widespread use of advertisements in television, newspapers and other media [8]. During this time, media vehicles were used as the main political communication tools to convey and disseminate political information to the eligible Malaysian voters [9].

For any contesting parties, political advertising is one of the best tools for them to disseminate their political messages. Another significant development in political advertising practices during this time was the entry of social media that had shaped and influenced political communication landscape in the country. However, as indicated earlier, the turning point in Malaysia's changing political campaigns was in the late 1960s where the use of newspapers as a subtle campaign tool for voters was apparent [10]. As a matter of fact, the contemporary political campaigns in Malaysia have evolved from mainly relying on the use video tapes, banners, and flyers to advertise their agenda to using mainstream media (electronic and printed) and the world wide web [6]. Before the entry of social media, in the 1999 general elections, the National Front (Barisan Nasional) being the ruling party which owns the leading mainstream television channels and newspapers took opportunity to utilise these media channels to the fullest to promote their party and aggressively hit out at the opposition parties and its candidates. This is not surprising as the National Front had been using the mainstream media as their campaign tool since the existence of these media vehicles in Malaysia [1,11,7,12,13,5,14].

In the 1995 general elections revealed that Malaysian society has become accustomed to advertising blitz especially via the media and other means of mass communication, [12]. In the most recent general elections held in 2013 where political advertising were utilised to the fullest, contesting parties spent millions of ringgit to reach their potential voters. To reclaim some lost seats in GE 12, the National Front had spent millions either on print advertisements, television and radio spots, billboard and other outdoor advertisements and 
also the social media channels to disseminate their political messages to Malaysians. This development clearly shows the increasing role of political advertisements in modern political campaigns. This high increase in expenditure to the marketing and advertising activities of the political campaigns could justify the attention political communication scholars gave to the study of political advertising [15]. Nevertheless, even though the National Front spent a million of ringgits in their campaigns, they still lost some important parliamentary seats to the opposition parties.

\section{Methodology}

The respondents employed in this study are the voters of the June 18, 2016 Sungai Besar by-election in Selangor. Convenience sampling is used in this study as respondents were selected because of their availability during the survey held on June 13, 2016 wherein data were collected on this date. The data of this study were generated from responses to questionnaires completed during the actual survey. A total of 360 questionnaires were provided. The trained enumerators assisted in the distribution of questionnaires to the voters of Sungai Besar. The questionnaire survey was employed because the survey method is a popular method used by researchers especially for political communication scholars to study election and voters. It is a method of data collection in which information is obtained directly from individual persons who are selected so as to provide a basis for making inferences about the larger population [1]. This method remains a dominant methodological tool for political communication analysis [22]. The SPSS 20 was employed in order to conduct frequency analysis. The analysis is used to extract the percentile of the profiles of respondents in terms of their gender and race, the percentage of selection of media for political issues during election campaigns and the choice of media vehicles by the respondents for information on political issues.

\section{Findings}

The present study involves a total of 360 respondents who are voters of Sungai Besar, Selangor by-election. The race distribution consisted of 64.3\% Malay, 24.4\% Chinese and $11.3 \%$ Indians. Meanwhile, gender distribution consisted of $51.0 \%$ male and $49 \%$ of female. Table 1 highlights the type of media that the respondents choose to get political information or political news during the election campaign. Based on the table below, it is understandable that most of the past research had indicated that mainstream media still play a significant role as the main political information source for voters in the rural and suburban areas. During the election campaigns, most of the political parties will work hard to highlight their presence inside the mainstream media to influence the political information efficacy and sense making process of the voters.

During an election campaign, mainstream media may compete with the social media. Based on the findings, early assumption can be highlighted to identify the information needs and information seeking activities among the voters. Traditional media such as television can be the main information needs for the voters to seek more information that can directly influence their political information efficacy. 
Table 1. The selection of media for political issues during by-election campaign

\begin{tabular}{|c|c|c|}
\hline \multirow{2}{*}{ Media } & frequency & percent \\
\cline { 2 - 3 } & $\mathbf{( f )}$ & $\mathbf{( \% )}$ \\
\cline { 2 - 3 } & & \\
\hline Mainstream media & 265 & 73.6 \\
\hline Social media & 95 & 26.4 \\
\hline Total & $\mathbf{3 6 0}$ & $\mathbf{1 0 0 . 0}$ \\
\hline
\end{tabular}

Source: Derived from current study

It is interesting to note that in Table 2, a major portion of the respondents who relied on television news consisted of $32.1 \%$, followed by news on radio $20.8 \%, 11.3 \%$ of newspaper advertisements and outdoor advertisements, 9.4\%. The response for social networking sites, though substantial was quite low with less than $6 \%$.

Table 2. Exposure to media vehicles for political issues during by-election campaign

\begin{tabular}{|l|c|c|}
\hline Media Vehicles & $\begin{array}{c}\text { frequency } \\
(\boldsymbol{f})\end{array}$ & $\begin{array}{c}\text { percent } \\
(\mathbf{\%})\end{array}$ \\
\hline Newspaper articles & 18 & 6.8 \\
Newspaper advertisements & 30 & 11.3 \\
News on television & 85 & 32.1 \\
Advertisements on television & 20 & 7.5 \\
News in Radio & 55 & 20.8 \\
Radio advertisements & 17 & 6.4 \\
Outdoor advertisements (Banners/posters/billboards) & 25 & 9.4 \\
Social networking sites & 15 & 5.7 \\
(political blogs, political online videos, party websites, & & \\
Political ads on cell phones) & & $\mathbf{1 0 0}$ \\
\hline Total & $\mathbf{2 6 5}$ & \\
\hline
\end{tabular}

Clearly, the results show that the television medium is still a popular medium that voters relied on for information on political issues. This is not at all surprising since people in the sub-urban and rural areas tend to see this medium as dependable and trustworthy for information that they need [22].

\section{Conclusion}

The purpose of this study is to investigate the types of communication tools usually used for political electoral process in Malaysia. The results of this study suggest that mainstream media play a significant role as the main political information source for voters to get political information. Despite the increasing popularity of social media sites, mainstream media is still relevant as tools of communication in short-term political campaigns, particularly for by-elections in rural and sub-urban areas where there are more middle aged people who are either baby boomers or from the gen x group of people aged 40 and above.

This study provides important implications for political parties wanting to participate in by-elections held in rural and sub-urban areas with a campaign period of two weeks or less. It is undeniable that although the rapid changes in communication technology has attracted the younger generation to embrace the latest communication tools; it is quite obvious that this new technology has very little effect on the more elderly voters in non-urban areas. Nevertheless, this phenomenon still needs to be studied in detail, and not merely grounded 
on assumptions as the results of this study is based on an exploratory study. As this study has a number of limitations, among which respondents were chosen only in one location, the findings cannot be generalized in other locations. For future studies, we recommend that varied samples are included to increase the generalizability of findings. However, this study has certainly provided an improved understanding of the types of communication and advertising tools usually used for political electoral process in Malaysia.

\section{References}

1. Mustafa K. Anuar. APME, 24, (2014).

2. Mohd Roslan, M. N., \& Mahmud, A. MJDES, 1. (2013).

3. Idid, S. A., \& Kee, C. P. ASS, 8. (2012).

4. McNair, B. (2011). An Introduction to Political Communication (fifth). Oxon: Taylor \& Francis Group,

5. Syed Arabi Idid dan Safar Hasim, Pilihan raya umum: Satu perspektif komunikasi politik. Kuala Lumpur: Dewan Bahasa dan Pustaka.(1993)

6. Kaid, L.L \& Holtz-Bacha, C. Handbook of Political Advertising. Thousand Oaks, CA: Sage. (2006)

7. Arfah Yusof, JK, 17 (2001)

8. Yaacob, R. A. I. R., Embong, A. M., Endut, M. N. A. A., \& Amin, A.-R. M. IJSSH, 4. (2014).

9. Ratnam, K. J., \& Milne, R. S. PA,43.(1970)

10. Ezhar Tamam and Manimaran Govindasamy. (2009). Political Communication Practices and Research in Malaysia. In L. W. Aw (Ed.), Political Communication in Asia (pp. 135-153). Oxon: Routledge.

11. Welsh, B. JD, 24 (2013)

12. Mustafa, K. Defining Democratic Discourses: The Mainstream Press. In F. L. Teik (Ed.), Democracy in Malaysia : Discourses and Practices (pp. 138-164). Surrey: Curzon. (2002)

13. Kuppuswamy, C. S. 10th General Election in Malaysia - an Analysis: It is now Malays vs Malays. India: South Asia Analysis Group. (1999)

14. Weiss, M. Introduction: Patterns and Puzzles in Malaysian Electrol Dynamics. In M. Weiss (Ed.), Electoral Dynamics in Malaysia : Findings from The Grassroots (pp. 116). Petaling Jaya, Selangor: Strategic Information and Research Development Centre. (2014)

15. Alqaseer, J. Political Advertising in Kuwait A Functional Discourse Analysis Florida State University 2008 For the Degree of Doctor in Philosophy in Accepted by: University of South Carolina. (2013)

16. Kaid, L. L. (Ed.). Handbook of Political communication research. New Jersey: Lawrence Erlbaum Associates. (2004)

17. Lancendorfer, K. M.. The role of attributions on voter response to political advertising. Michigan State University.(2005)

18. Willnat, L and Annette J. Aw. Political Communication in Asia: Challenges and Opportunities. In L. K. Lynda, Handbook of Political Communication Research (pp. 479-505). New Jersey: Lawrence Erlbaum Associates, Publishers.(2004)

19. Case, W. MJDES, 1 (2013).

20. Sualman, I., Shariff, S. Z., Yaakop, S. H., \& Mahmood, A. IPEDR, 64 (2013).

21. Mun, W., \& Li, L. SEARCH, 3 (2011).

22. Syed Arabi Idid dan Safar Hasim. Pilihan raya umum: Satu perspektif komunikasi politik. Kuala Lumpur: Dewan Bahasa dan Pustaka (1993) 